\title{
Za doc. JUDr. Renatou Veselou, Ph.D.
}

Dne 6. února 2019 právněhistorickou obec navždy neočekávaně opustila kolegyně doc. JUDr. Renata Veselá, Ph.D.

Renata Veselá, rozená Černá, se narodila 26. června 1959 v Kutné Hoře v rodině veterináře. Rodina se však brzy přestěhovala do Brna, a tak zbytek života Renaty Veselé byl spojen s touto moravskou metropolí. Zde vystudovala gymnázium, po kterém hned byla přijata na brněnskou právnickou fakultu. Tu v roce 1982 vystudovala s červeným diplomem, což tehdy umožňovalo automatické získání titulu JUDr.

JUDr. Renata Veselá hned po studiu krátce nastoupila do právnické praxe brněnské Zbrojovky, tehdy nazývané ZJŠ (Závody Jana Švermy). Zde působila v letech 1982-1985. Postavení podnikové právničky jí však nepřirostlo př́liš k srdci, a tak v roce 1985 využila nabídky katedry dějin státu a práva tehdejší Univerzity J. E. Purkyně v Brně (dnešní Masarykovy univerzity) a nastoupila na místo interní aspirantky. Katedra dějin státu a práva této fakulty se jí stala osudnou pro zbytek života.

Okamžitě se zapojila do života katedry a přijala první vědecký úkol (aspirantský úkol): dějiny studentských spolků v Brně do roku 1948. Jednalo se zcela neprobádané téma a tak výstupy byly výsledkem čistě archivního výzkumu. Na toto téma postupně publikovala několik článků v časopisech Universitas, Časopis Matice moravské a Acta Universitatis Carolinae HUCP. V roce 1991 přešla na řádné místo odborné asistentky katedry a v roce 1995 aspirantskou práci obhájila již jako doktorskou disertační práci. Ve stejném roce ji publikovala knižně pod názvem Spolkový zákon v praxi některých brněnských fakultních spolků (1919-1952), vyd. v Brně: Masarykova univerzita, 1995. 126 s. ISBN 80-210-111-4.

Od počátku svého působení na katedře se zapojovala do řešení i dalších témat. Zejména jí byly blízké dějiny rodinného práva. Z této oblasti publikovala celou řadu studií a článků v zahraničních i domácích časopisech a sbornících. Z knižních zpracování připomeňme zejména monografii Rodina a rodinné právo (Historie, současnost a perspektivy). Praha: Eurolex Bohemia, 2003. 262 s. ISBN 80-86432-48-3, jež v roce 2005 vyšla i ve druhém vydání.

Renata Veselá se již jako aspirantka zapojila i do pedagogického procesu. Prošla postupně všemi pedagogickými disciplínami - československými dějinami státu a práva, obecnými dějinami státu a práva, dějinami soukromého práva a římským právem. Nakonec zakotvila právě v posledně jmenovaném oboru.

Kromě brněnské právnické fakulty pedagogicky působila v letech 1991-1994 na Právnické fakultě Univerzity Palackého v Olomouci, v letech 2001-2003 na soukromé Vysoké 
škole Karla Engliše a v letech 2003-2012 na soukromé Vysoké škole B.I.B.S. (Brno International Business School).

U studentů byla velmi oblíbená, zejména kvůli svému přístupu k pojetí římského práva, které se, na rozdíl od svých kolegů, nesnažila nadřadit nad ostatní právněhistorické disciplíny, ale začlenit ho do celého komplexu právních dějin. Tento nadhled získala právě tím, že všemi těmito právněhistorickými disciplínami prošla.

Více jak pedagogická práce ji ale zajímala práce vědecká a publikační. Je autorkou dlouhé řady článků a spoluautorkou řady monografií. Zejména je třeba zdůraznit několik monografií na téma integrace v Evropě (např́klad Myšlenka evropské integrace a její vyústění v realitě EU (nástin problematiky). Ostrava: KEY Publishing, 2006. 102 s. ISBN 80-87071-05-0; Historie integračních koncepcí a jejich vyústění v realitě EU. Ostrava: KEY Publishing, 2007. 214 s. ISBN 978-80-87071-53-3; Nástin sbližování práva ČR s právem Evropské unie ve vybraných dokumentech. Ostrava: KEY Publishing, 2007. 278 s. ISBN 978-80-87071-52-6; Geschichte von Integrationskonzeption in Europa bis 1945. München: Verlag Dr. Hut, 2009. 115 s. ISBN 978-3-86853-065-0; Geschichte von Integrationskonzeptionen und ihre Äußerung in der Realität der EU. Brno: NOVPRESS, 2009. 184 s. ISBN 978-80-87342-02-2; Podíl českých zemí na integračních a unifikačních snahách v Evropě. Ostrava: KEY Publishing, 2009. 214 s. ISBN 978-80-7418-048-4). Práce, jejichž spoluautory byli Ladislav Vojáček a Karel Schelle, vzešly z výzkumného záměru Evropský kontext vývoje českého práva po roce 2004, jenž po řadu let řešila brněnská právnická fakulta. Podílela se ovšem i na dalších výzkumných a grantových úkolech jak brněnské, tak pražské právnické fakulty.

V roce 1992 absolvovala studijní pobyt v Oxfordu na University of Warwick, University of Southampton a v roce 1994 kurs amerického práva v Chicagu.

Renata Veselá se zapojila i do psaní učebních pomůcek, a to nejen z římského práva, ale zejména $\mathrm{z}$ českých dějin státu a práva a obecných dějin státu a práva, př́ípadně z dějin soukromého práva. Dokonce její jméno najdeme i pod první porevoluční učebnicí práva kanonického.

Vystoupila na řadě zahraničních i domácích vědeckých konferencí, z nichž je tř̆eba upozornit na Mezinárodní vědecký kongres XLVII SIHDA „Palingenesia: Textual reconstruction“. Oxford, 21.-25. zář́i 1993; Mezinárodní konferenci „Unjust Enrichment and the Law of Contract, Kluwer Law International“. The Hague, The Netherlands, 2001; nebo Mezinárodní kongres „ICHRPI - Mezinárodní komise pro dějiny zastupitelských a parlamentních institucí" (54th Conference of the International Commission for History of Representative \& Parliamentary Institutions in Prague). Praha, Senát České republiky, 2004.

Její bibliografie čítá přes 230 bibliografických záznamů.

Zapojila se i do organizátorské práce. Stála u zrodu mezinárodní právněhistorické společnosti The European Society for History of Law, která vznikla v Brně v roce 2009, v níž od počátku zastávala některou z předních funkcí. Také publikovala několik článků v mezinárodním časopise Journal on European History of Law, který tato společnost vydává. Rovněž se aktivně zapojila do psaní hesel pro Encyklopedii českých právních dějin, kterou společnost spoluorganizuje od roku 2015.

O velkém tematickém rozsahu Renaty Veselé konečně svědčí její habilitační práce Vybrané historické zdroje současného rodinného práva, kterou v roce 2015 obhájila 
na Právnické fakultě Univerzity Komenského v Bratislavě a která vyšla v roce 2013 knižně (Ostrava: KEY Publishing, 2013. 177 s. ISBN 978-80-7418-189-4).

Nevyhýbala se ani právní praxi, od počátku 90. let byla členkou České advokátní komory.

Bohužel svoji práci i své přátele opustila náhle po delší nemoci 6. února 2019 ve věku 59 let. Výsledky její práce nám ji budou vždy připomínat.

doi: 10.14712/2464689X.2019.12

Karel Schelle 